\title{
DESAIN PENYELENGGARAAN PENYULUHAN MENDUKUNG PROGRAM KAWASAN PERTANIAN SEJAHTERA (SAPIRA) DI KABUPATEN PRINGSEWU PROVINSI LAMPUNG
}

\author{
Fauziah Yulia Adriyani \\ Balai Pengkajian Teknologi Pertanian Lampung \\ Jl. ZA Pagar Alam No. 1A Rajabasa Bandar Lampung \\ E-Mail: fyadriyani@gmail.com
}

\section{RINGKASAN}

Pelaksanaan program pembangunan pertanian membutuhkan peran penyuluh sebagai pendamping yang memiliki kinerja baik. Akan tetapi, penyelenggaraan penyuluhan belum dirancang untuk mendukung pelaksanaan program pembangunan pertanian. Hal ini menyebabkan penyuluh sebagai ujung tombak dan pendamping yang berinteraksi langsung dengan sasaran dan pelaksana program, belum dapat bekerja dengan optimal. Berdasarkan potensi dan kendala yang dihadapi, desain penyelenggaraan penyuluhan di Kabupaten Pringsewu pada tahap awal difokuskan pada peningkatan kemampuan pos penyuluhan pedesaan dan kelompok tani sebagai kelas belajar petani dalam upaya mengatasi kekurangan tenaga penyuluh serta meningkatkan kemampuan penyuluh dalam aspek manajemen. Selain sinergitas antar instansi dalam pelaksanaan program pembangunan pertanian juga diperlukan sinergitas metode penyuluhan yang digunakan.

Kata Kunci: Lampung, penyuluhan, SAPIRA.

\section{PERNYATAAN KUNCI}

Program pembangunan pertanian sudah banyak dilakukan oleh Kementerian Pertanian. Keberhasilan program cukup bervariasi antar daerah, sebagai contoh adalah pemberian modal pada petani melalui Gabungan Kelompok Tani (Gapoktan) untuk usaha agribisnis di wilayah perdesaan atau yang dikenal dengan PUAP (Pengembangan Usaha Agribisnis Pedesaan). Pelaksanaan program ini dinilai cukup berhasil dibeberapa daerah tetapi di sebagian daerah lainnya justru mengalami kegagalan dan menimbulkan permasalahan baru. Namun hal ini tidak menyurutkan pemerintah untuk dapat meningkatkan taraf hidup masyarakat melalui pelaksanaan program pembangunan pertanian lainnya seperti program Kawasan Pertanian Sejahtera (SAPIRA) yang memiliki konsep pengembangan kawasan.

Pelaksanaan suatu program tidak terlepas dari peran penyuluh sebagai pendamping dan agen perubahan. Lebih lanjut, sebagai bagian dalam suatu sistem penyelenggaraan penyuluhan, kinerja 
penyuluh akan sangat dipengaruhi oleh bagaimana sistem tersebut berjalan. Hal ini penting bagi pemerintah daerah untuk membuat suatu desain penyelenggaraan penyuluhan yang merupakan salah satu kunci dalam mendukung keberhasilan program pembangunan pertanian pada umumnya.

\section{REKOMENDASI KEBIJAKAN}

Keberhasilan program pembangunan pertanian diawali dengan identifikasi potensi wilayah dan permasalahan yang tepat sehingga dapat ditentukan strategi terbaik yang dapat diterapkan dalam pelaksanaan kegiatan. Berlakunya UndangUndang Otonomi Daerah berdampak pada keberagaman/variasi dalam penyelenggaraan penyuluhan, sebagai salah satu kabupaten di Provinsi Lampung, Kabupaten Pringsewu.

Kabupaten Pringsewu memiliki kelebihan terutama dengan adanya dukungan Pemda, potensi wilayah yang sesuai untuk pengembangan komoditas strategis nasional seperti padi dan jagung, serta keberadaan kelembagaan petani yaitu Poktan dan Gapoktan. Kelemahan penyelenggaraan penyuluhan meliputi keterbatasan jumlah tenaga penyuluh serta kemampuan manajemen baik penyuluh dan pengurus Poktan yang masih rendah.

Berdasarkan potensi dan kendala yang dihadapi, desain penyelenggaraan penyuluhan di kabupaten pringsewu pada tahap awal difokuskan pada peningkatan kemampuan posluhtan dan Poktan sebagai kelas belajar petani dalam upaya mengatasi kekurangan tenaga penyuluh serta meningkatkan kemampuan penyuluh dalam aspek manajemen. Selain sinergitas antar instansi dalam pelaksanaan program SAPIRA juga diperlukan sinergitas metode penyuluhan yang digunakan.

\section{PENDAHULUAN}

\section{Latar Belakang}

Penerapan sistem penyuluhan bukanlah hal yang statis. Dengan diterapkannya UU Otonomi Daerah, Provinsi dan kabupaten memiliki kewenangan untuk mengatur daerahnya berdasarkan sumberdaya serta keterbatasan yang dimiliki. Hal ini berdampak pada perbedaan sistem penyuluhan pertanian tingkat provinsi. Penyelenggaraan penyuluhan di tingkat kabupaten. Selanjutnya, di tingkat kecamatan terdapat Balai Penyuluhan Pertanian yang melaksanakan tugas-tugas penyuluhan.

Bagaimanapun juga, Balai Pengkajian Teknologi Pertanian (BPTP) sebagai perpanjangan tangan Kementerian Pertanian (Kementan) harus dapat menjalin hubungan harmonis dengan pemerintah daerah (Pemda) untuk mencapai tujuan pembangunan pertanian nasional yaitu mencapai kedaulatan pangan dan kesejahteraan petani. Salah satu indikator kesejahteraan petani secara ekonomi adalah 
peningkatan pendapatan yang dapat dicapai melalui peningkatan produksi, nilai tambah dan daya saing produk yang salah satu caranya dapat dicapai dengan pelaksanaan penyuluhan.

Peningkatan efisiensi dapat dicapai melalui pelaksanaan usaha pertanian dalam skala ekonomis yang didasarkan pada pengelolaan suatu kawasan pengembangan. Selain itu, peningkatan efisiensi juga dapat dilakukan dengan penerapan teknologi. Dengan demikian, program pengembangan SAPIRA yang merupakan suatu model diseminasi inovasi pertanian hasil Balitbangtan maupun luar Balitbangtan adalah salah satu strategi dalam pencapaian program pembangunan nasional.

Pengembangan SAPIRA dilakukan melalui pemberdayaan masyarakat dimana peran pemerintah lebih sebagai katalisator dan motivator sehingga masyarakat dapat membantu dirinya sendiri untuk tumbuh dan berkembang dengan tetap memperhatikan aspek berkelanjutan sumberdaya dan lingkungan sehingga mampu berkelanjutan (Anonim, 2019). Dengan demikian, sesuai dengan definisi penyuluhan dalam UU No. 16 Tahun 2003, penyuluhan memegang peranan penting sebagai suatu proses pembelajaran informal yang ditujukan bagi masyarakat yang dalam hal ini adalah petani agar memiliki kemauan dan kemampuan untuk dapat meningkatkan kapasitasnya dalam memperoleh informasi baik pasar maupun teknologi yang dibutuhkan. Lebih lanjut, melalui penyuluhan, petani juga diharapkan dapat mengakses sumber permodalan dan sumberdaya yang dibutuhkan sehingga pada akhirnya mereka mampu meningkatkan produktivitas dan efisiensi dalam berusahatani yang berdampak pada peningkatan pendapatan dan kesejahteraan dengan memperhatikan kelestarian lingkungan.

Sebagai suatu kawasan percontohan, maka perencanaan pelaksanaan SAPIRA perlu dilakukan dengan sebaik-baiknya dengan mempertimbangkan potensi lokasi dan juga kelemahan serta ancaman yang dapat muncul dalam pelaksanaan kegiatan nantinya. Berdasarkan hal tersebut, perlu dilakukan analisis potensi dan kendala yang ada dalam upaya mendapatkan strategi terbaik berkaitan dengan pelaksanaan penyuluhan yang dapat digunakan dalam mencapai keberhasilan pelaksanaan program SAPIRA.

\section{Tujuan}

1. Mengidentifikasi dan menganalisis potensi dan permasalahan yang dimiliki oleh Kabupaten Pringsewu.

2. Membuat desain dan strategi penyelenggaraan penyuluhan dalam mendukung program SAPIRA di Kabupaten Pringsewu. 


\section{SITUASI TERKINI}

\section{Potensi Kabupaten Pringsewu dalam Program SAPIRA}

Berdasarkan keberhasilan dan permasalahan yang masih ditinggalkan dalam pelaksanaan kegiatan Sekolah Lapang (SL) mendukung program Desa Mandiri Benih (DMB), pelaksanaan program SAPIRA di suatu wilayah harus memperhatikan potensi wilayah dan permasalahan yang mungkin dihadapi.

\section{Dukungan Pemerintah Daerah}

Dukungan pemerintah daerah merupakan kekuatan yang dimiliki oleh Kabupaten Pringsewu dalam pelaksanaan dan keberkelanjutan program pembangunan pertanian. Bupati Pringsewu yang memiliki latar belakang di bidang pendidikan, selalu mendorong pelaksanaan penyelenggaraan penyuluhan. Salah satu dukungan Bupati Pringsewu pada tahun 2019 adalah pelaksanaan kaji terap padi varietas lokal "Lumbung Sewu Cantik" yang diarahkan sebagai fokus kegiatan dalam rangka pelepasan varietas tersebut.

\section{Potensi Wilayah}

Kabupaten Pringsewu memiliki wilayah administrasi seluas $625 \mathrm{~km} 2$ atau setara dengan 62.510 ha yang sebagian besarnya dimanfaatkan untuk lahan pertanian. Luas lahan sawah berkisar 13.862 ha dan lahan kering seluas 35.656 ha.

Komoditas utama di Kabupaten Pringsewu adalah padi dan jagung. Selain tanaman pangan, cabai merah dan bawang merah juga merupakan komoditas hortikultura unggulan serta kakao yang merupakan komoditas unggulan perkebunan (Tabel 1).

Tabel 1. Luas Tanam, Panen, Produksi dan Produktivitas Komoditas Utama di Kabupaten Pringsewu Tahun 2018

\begin{tabular}{|c|c|c|c|c|c|}
\hline No & $\begin{array}{l}\text { Komo- } \\
\text { ditas }\end{array}$ & $\begin{array}{l}\text { Luas } \\
\text { tanam } \\
\text { (ha) }\end{array}$ & $\begin{array}{l}\text { Luas } \\
\text { Panen } \\
\text { (ha) }\end{array}$ & $\begin{array}{l}\text { Produksi } \\
\text { (ton) }\end{array}$ & $\begin{array}{l}\text { Provitas } \\
\text { (ton/ha) }\end{array}$ \\
\hline 1. & $\begin{array}{l}\text { Padi } \\
\text { Sawah }\end{array}$ & 30.303 & 29.945 & 62.032 & 5,35 \\
\hline 2. & $\begin{array}{l}\text { Padi } \\
\text { Ladang }\end{array}$ & 329 & 338 & 1.014 & 3 \\
\hline 3. & Jagung & 6.134 & 5.792 & 28.960 & 5 \\
\hline 4. & Kedelai & 351 & 252 & 299.9 & 1,19 \\
\hline 5. & $\begin{array}{l}\text { Cabe } \\
\text { Merah }\end{array}$ & 481,5 & 481,5 & $4.339,5$ & 9,01 \\
\hline 6. & $\begin{array}{l}\text { Bawang } \\
\text { Merah }\end{array}$ & 29 & 29 & 258 & 12 \\
\hline 7. & Kakao & 4.131 & & & \\
\hline 8. & Karet & 2.920 & & & \\
\hline
\end{tabular}

Sumber data: Program Penyuluhan Kabupaten Pringsewu

\section{Keberadaan Poktan dan Gapoktan}

Kelompok tani (Poktan) di Kabupaten Pringsewu tercatat 797 Poktan yang sebagian besar masuk dalam kelas lanjut (557 Poktan) dan Gapoktan sejumlah 117 Gapoktan yang sebagian besar belum berbadan hukum (69 Gapoktan). Selain itu, terdapat 97 Pos Penyuluhan Desa (Posluhdes). Apabila dibandingkan dengan jumlah pekon/desa dan kelurahan yang terdapat di Kabupaten Pringsewu yaitu sebanyak 131 buah maka beberapa pekon/desa belum memiliki Posluhdes. 


\section{Permasalahan yang Dihadapi dalam Program Sapira di Kabupaten Pringsewu}

\section{Ketersediaan Penyuluh}

Berdasarkan data Program tahun 2019, Kabupaten Pringsewu memiliki 9 kantor Balai Penyuluhan Pertanian (BPP) yang tersebar di semua kecamatan. Dari segi ketenagaan penyuluh, Kabupaten Pringsewu memiliki 36 orang penyuluh PNS, 27 orang THL-TBPP pusat, 3 orang THL-TBPP daerah. Jumlah penyuluh ini masih dirasakan kurang mengingat jumlah wilayah binaan mencapai 131 desa. Untuk itu, Kabupaten Pringsewu memanfaatkan beberapa petani sebagai penyuluh swadaya sebanyak 54 orang.

\section{Kemampuan Manajemen Penyuluh}

Berdasarkan informasi dari pejabat struktural dan fungsional Dinas Pertanian Pringsewu serta hasil pelaksanaan kegiatan SL-DMB Padi, selain kemampuan teknis, penyuluh pertanian di Kabupaten Pringsewu pada khususnya memiliki keterbatasan pengetahuan dan keterampilan di bidang manajemen. Hal ini berdampak pada materi penyuluhan yang lebih banyak bahkan hampir semuanya berkaitan dengan aspek teknis. Padahal dalam pengembangan suatu kawasan agribisnis, pengetahuan mengenai aspek manajemen memegang peranan penting.

\section{METODOLOGI}

Makalah ini dibuat berdasarkan data potensi wilayah Kabupaten Pringsewu yang dikaitkan dengan program penyuluhan yang tertuang dalam Programa Kabupaten tahun 2019, kegiatan penyuluhan dan pengkajian yang pernah dilaksanakan di Kabupaten Pringsewu, serta studi pustaka penelitian terkait. Metode yang digunakan adalah desk study, wawancara dengan informan kunci dan pengamatan lapangan. Analisis data dilakukan secara deskriptif sehingga didapatkan strategi dalam pelaksanaan program SAPIRA di Kabupaten Pringsewu.

\section{ANALISIS DAN ALTERNATIF SOLUSI/PENANGANAN}

\section{Desain Penyelenggaraan Penyuluhan Mendukung Program SAPIRA.}

Kegiatan penyelenggaraan penyuluhan berada di Bidang Penyuluhan Dinas Pertanian Kabupaten Pringsewu. Latihan, Kunjungan dan Supervisi (LAKU SUSI) merupakan metode yang digunakan dalam penyelenggaraan penyuluhan. Pada LAKU SUSI, pendekatan penyuluhan dilakukan dengan memadukan antara pelatihan bagi penyuluh dan ditindaklanjuti dengan kunjungan/pendampingan kepada sasaran utama secara terjadwal. Pendekatan ini dinilai cukup berhasil dalam meningkatkan pengetahuan, keterampilan serta sikap secara berjenjang. Akan tetapi yang perlu diperhatikan dalam pendekatan ini adalah kesesuaian materi untuk 
menjawab permasalahan. Identifikasi masalah menjadi kunci keberhasilan pelaksanaan penyuluhan.

Tugas penyuluh sebagai agen perubahan adalah mengidentifikasi masalah, nilai, tujuan dan tipe operasional organisasi; menjelaskan masalah dan kebutuhan program melalui ukuran kebijakan dan kegiatan; menggerakkan dan mengembangkan sumberdaya manusia dan alam; menggabungkan semua sumberdaya yang ada dalam penerapan struktur kekuasan, komunikasi dan tindakan yang dilakukan organisasi dalam melaksanakan program (Boyle, 1981).

Berdasarkan hasil analisis potensi wilayah, wawancara dengan informan kunci (pejabat struktural dan penyuluh lapang) di Kabupaten Pringsewu serta pengalaman dalam pelaksanaan kegiatan SL terintegrasi Desa Mandiri Benih, maka diketahui beberapa potensi yang dapat menjadi peluang dan kekuatan serta permasalahan yang dapat melemahkan dan menghambat keberhasilan pelaksanaan penyuluhan dalam mendukung pengembangan program kawasan pertanian sejahtera (SAPIRA) di Kabupaten Pringsewu.

\section{Pemanfaatan Posluhdes dan Poktan/ Gapoktan sebagai Kelas Belajar}

Pengembangan SAPIRA diharapkan dapat memberikan manfaat berupa (1) meningkatnya muatan inovasi pertanian dalam pengembangan usaha agribisnis di suatu kawasan, (2) meningkatnya efisiensi sumberdaya pertanian, dan (3) meningkatnya pendapatan dan kesejahteraan masyarakat. Sinergitas dan keterkaitan program baik pusat maupun daerah diperlukan untuk mewujudkan SAPIRA perlu adanya.

Pemberdayaan adalah upaya meningkatkan kekuatan dari ketidakberuntungan/ kesulitan, pemberian kekuatan/daya kepada individu atau kelompok sehingga mereka memiliki daya sendiri serta mampu memberikan daya kepada yang belum berdaya (Ife, 2002). Seperti yang tercantum dalam Permentan (2010) tentang pembinaan Pusat Pelatihan Pertanian Pedesaan Swadaya (P4S), kegiatan P4S berkaitan dengan pemberdayaan petani melalui proses pembelajaran secara berkelanjutan sehingga terjadi perubahan perilaku, sikap dan pola pikir menjadi petani yang berwawasan agribisnis dan modern.

Kegiatan pelatihan diperlukan dalam pengembangan masyarakat karena melalui kegiatan pelatihan dapat menumbuhkan, membangun dan mengembangkan semangat belajar (Theresia et al, 2014). Tanpa pengetahuan yang memadai, petani tidak dapat mengadopsi teknologi dengan baik. Selanjutnya, pelatihan dalam program pengembangan masyarakat tidak selalu memerlukan fasilisator dari luar (Theresia et al, 2014). Penggunaan fasilisator dari dalam kelompok lebih baik dengan pertimbangan, 
mereka lebih mengetahui hal-hal yang lebih sesuai dan diminati oleh masyarakatnya.

Berdasarkan jumlah posluhdes dan Poktan/Gapoktan serta keterbatasan jumlah tenaga penyuluh, keberadaan posluhdes dan Poktan/Gapoktan sebagai kelas belajar dapat lebih ditingkatkan. Dalam hal ini, peran pemerintah diperlukan dalam upaya mempersiapkan petani agar mampu dan terampil mengelola kegiatan pelatihan. Pelatihan berjenjang dapat juga menjadi solusi pemecahan masalah ketersediaan tenaga penyuluh.

Tujuan pembentukan Poktan dan Gapoktan selain menjadi wadah/tempat pembelajaran petani, juga dalam rangka penguatan kerjasama sehingga usahatani menjadi lebih ekonomis dan efisien (Hanggana, 2017). Lebih lanjut, pemanfaatan kelompok baik Poktan, Gapoktan atau kelompok usaha lainnya dinilai cukup efektif dalam melaksanakan program Kementerian Pertanian (Kementan). Mekanisme komunikasi dalam kelompok memungkinkan petani meningkatkan pemahaman terhadap pesan (Ingram dan Simon, 2002) sehingga diharapkan mampu meningkatkan adopsi inovasi oleh petani sehingga mereka mampu meningkatkan produksi usahataninya yang berimbas pada peningkatan pendapatan dan kesejahteraan.

\section{Penyesuaian Materi Pelatihan}

Kegiatan penyuluhan pertanian tidak terlepas dari penyediaan materi inovasi. Materi yang disampaikan harus disesuaikan dengan kebutuhan sasaran. Kebutuhan petani dalam meningkatkan pendapatan dan kesejahteraannya tidak selalu berhubungan dengan teknis budidaya. Hal penting yang perlu juga diperhatikan adalah dukungan dan kemudahan yang menjamin terlaksananya penerapan inovasi, yaitu keberadaan saprodi, kemudahan permodalan, pemasaran hasil, penelitian spesifik lokasi, dan kelembagaan penunjang lainnya (Lionberger, 1982).

Pengembangan kelembagaan usaha agribisnis dalam program SAPIRA difokuskan pada pemberdayaan kelembagaan petani, antara lain kelembagaan sarana produksi, jasa alat dan mesin pertanian, kelembagaan produksi/ usahatani, kelembagaan panen dan pascapanen, kelembagaan pengolahan hasil, kelembagaan pemasaran, yang didukung kemudahan akses terhadap kelembagaan permodalan, dan asuransi pertanian serta kelembagaan penyuluhan pertanian yang kuat. Berdasarkan hal tersebut, penyuluhan pertanian tidak selalu berhubungan dengan aspek teknis akan tetapi juga berkaitan dengan aspek manajemen.

$$
\text { Perlunya pengembangan }
$$

kelembagaan tersebut membutuhkan kemampuan pengurus Poktan/Gapoktan 
sebagai kelompok ekonomi petani dalam aspek manajemen yang kuat. Sebagai fasilitator dan pendamping program pembangunan, kemampuan penyuluh dalam aspek manajemen perlu ditingkatkan terlebih dahulu sebagai bekal bagi mereka dalam pelaksanaan pendampingan.

\section{Pelaksanaan Metode Penyuluhan Terintegrasi}

Materi, metode dan media yang digunakan penyuluh bukan hal yang baku. Seorang penyuluh dengan materi yang sama, dapat menggunakan metode dan media yang berbeda dengan penyuluh yang lain. Bahkan seorang penyuluh dapat menerapkan beberapa metoda untuk materi yang sama.

Perbedaan pemilihan metode dan media penyuluhan ditentukan oleh banyak faktor. Pemilihan metoda umumnya berdasarkan kondisi sasaran baik kebutuhan, pengalaman dan pengetahuannya. Lebih lanjut, kemampuan komunikasi dan pengetahuan teknis yang dimiliki penyuluh juga dapat menjadi pertimbangan dalam pemilihan metode, sehingga dapat dikatakan bahwa tidak ada satupun metoda yang paling efektif dan efisien diterapkan di semua lokasi. Sebagai contoh, penggunaan metoda ceramah mungkin akan efektif pada sasaran memiliki sikap selalu ingin mencoba hal baru meskipun tingkat pengetahuan sasaran (petani) rendah (setingkat SD pada pendidikan formal). Tetapi keberhasilan metode ini harus ditunjang oleh kemampuan penyuluh dalam menguasai teknologi dan berkomunikasi dengan baik.

Berbeda dengan kondisi daerah dan tingkat pengetahuan sasaran yang sama tetapi mayoritas merupakan pengadopsi lambat yang membutuhkan bukti keberhasilan inovasi serta selalu berprasangka terhadap hal baru, maka metoda ceramah akan sangat tidak cocok untuk diterapkan. Pada kondisi sasaran yang seperti ini, penyuluh sebaiknya menggunakan metode demplot yang dilaksanakan oleh beberapa orang petani yang berbeda dan dilengkapi dengan metode pelaksanaan Sekolah Lapang. Metode demonstrasi memiliki tingkat kesesuaian yang tinggi karena sasaran dapat melihat hasil dan dampak penerapan teknologi secara langsung di lapangan (Adriyani dan Kiswanto, 2017). Keberadaan demplot juga penting dalam membangun persepsi positif petani terhadap teknologi yang pada akhirnya dapat mempengaruhi perilaku petani dalam menerapkan teknologi (Wijayanto dan Kiswanto, 2008). Lebih lanjut, hasil penelitian (Sustiyah dkk, 2012) menunjukkan pelaksanaan pelatihan dan demonstrasi penerapan teknologi budidaya di lapangan mampu meningkatkan pengetahuan petani mengenai bahaya pirit.

Selain demonstrasi, metode SL (Sekolah Lapang) yaitu teknik pembelajaran 
dengan melihat dan berkunjung ke lokasi pertanaman, sangat membantu para petani untuk meningkatkan pengetahuan yang kemudian diaplikasikan pada lahan yang mereka miliki (Triwidarti dkk, 2015).

Berdasarkan pengalaman pengkajian SL-DMB padi, pelaksanaan beberapa metode penyuluhan seperti demplot, pelatihan melalui bimtek sekolah lapang, temu lapang yang dilengkapi pameran inovasi serta penyiaran informasi melalui media massa TV mampu meningkatkan keberhasilan kegiatan Pengembangan Model Kawasan Sekolah Lapang Mandiri Benih Padi di Kabupaten Pringsewu (Adriyani dkk, 2017).

Lebih lanjut, dalam upaya meningkatkan keberhasilan program SAPIRA, beberapa metode yang dapat diterapkan antara lain:

- Kaji Terap yang dilanjutkan dengan demplot penerapan inovasi teknologi. Metode ini bertujuan untuk meningkatkan peran aktif petani dalam memilih teknologi inovasi yang paling sesuai dan meningkatkan keyakinan petani akan keunggulan teknologi.

- Sekolah Lapang- bertujuan untuk meningkatkan pengetahuan dan keterampilan petani terhadap teknologi secara terjadwal dan terstruktur. Narasumber berasal dari sumber inovasi seperti Badan Litbang Pertanian.
- Latihan dan Kunjungan atau pelatihan berjenjang yang fokus pada materi pengembangan posluhdes/ Poktan sebagai kelas belajar dan aspek manajemen.

- LAKU SUSI dengan memanfaatkan pertemuan kelompok.

\section{REFERENSI}

Adriyani, F.Y., Kiswanto. 2016. Kinerja Penyuluhan dalam Pelaksanaan SL PTT Padi Sawah Irigasi di Provinsi Lampung. Prosiding Seminar Nasional Agroinovasi Spesifik Lokasi Untuk Ketahanan Pangan Pada Era Masyarakat Ekonomi ASEAN. Lampung. Halaman 360365.

Adriyani, F.Y., dkk. 2017. Pengembangan Model Kawasan Sekolah Lapang Mandiri Benih Padi di Lampung. Balai Pengkajian Teknologi Pertanian (BPTP). Lampung. Halaman 33.

Badan Pusat Statistik. 2017. Laporan Bulanan Data Sosial Ekonomi. Badan Pusat Statistik.

Boyle, P.G. 1981. Planning Better Program. McGraw-Hill. Inc. New York. Halaman 241.

Dinas Pertanian Pringsewu. 2019. Program Penyuluhan Kabupaten Pringsewu. Dinas Pertanian Pringsewu.

Hanggana, S. 2017. Analisis Kelemahan Regulasi Poktan, Gapoktan, UPJA, dan LKM-A Dalam Peningkatan Pendapatan Petani. Analisis Kebijakan Pertanian. Vol. 15 (2) 2017: pp 137-149.

Ife, J. 2002. Community Development. Longman. Australia. Halaman 309.

Ingram, P., Simons, T. The Transfer of Experience in Groups of Organizations: Implications for Performance and 
Competition. Management Science 48 (12): pp 1517-1533.

Lionberger, H.F. 1982. Communication Strategies A Guide for Agricultural Change Agent.

Peraturan Menteri Pertanian Nomor: 03/Permentan/Pp.410/1/2010

Tentang Pedoman Pembinaan Kelembagaan Pelatihan Pertanian Swadaya. Halaman 322

Adji, F.Y., Sustiyah, Sulistiyanto, Y. 2012. Peningkatan Pengetahuan Petani tentang Bahaya Pirit (Fes--2) dan Upaya Penanggulangannya pada Usaha Pertanian Pasang Surut di Daerah Mentaren Kalimantan Tengah.

https://jurnalagriepat.wordpress.co $\mathrm{m}$ /2012/03/ 11/ peningkatanpengetahuan-petanitentang-bahayapirit-fes2 sustiyah/.

Andini, K.S., Nugraha, P.G.P., Martikanto, T, Theresia, A. 2014. Pengembangan Masyarakat
Community Development Acuan bagi Praktisi, Akademisi, dan Pemerhati Pengembangan Masyarakat. UPT UNS Press. Surakarta.

Suyadi, B., Sukidin, Triwidarti, T. 2015. Peran Kelompok Tani Sampurna dalam Meningkatkan Pengetahuan Petani dan Hasil Produksi Padi di Desa Jenggawah Kecamatan Jenggawah Kabupaten Jember. Artikel Ilmiah Mahasiswa. I (1): 1-6.

Undang-undang No. 16. 2006. Sistem Penyuluhan Pertanian Peternakan Perkebunan dan Kehutanan.

Wijayanto, B., Kiswanto. 2008. Model Laboratorium Lapang dalam SLPTT sebagai Upaya untuk Membangun Persepsi Petani terhadap PTT. Prosiding Seminar Hasil Penelitian dan Pengkajian Teknologi Pertanian. Halaman 216221. 